\title{
$\square$
}

\section{The Effects of Recessions Across Demographic Groups}

\author{
Kristie M. Engemann and Howard J. Wall
}

\begin{abstract}
The burdens of a recession are not spread evenly across demographic groups. As the public and media noticed, from the start of the current recession in December 2007 through June 2009 men accounted for more than three-quarters of net job losses. Other differences have garnered less attention but are just as interesting. During the same period, the employment of single people fell at more than twice the rate that it did for married people and the decline for black workers was one and a half times that for white workers. To provide a more complete understanding of the effect of recessions, this paper examines the different effects of this and previous recessions across a range of demographic categories: sex, marital status, race, age, and education level. (JEL E32, J20, R12)
\end{abstract}

Federal Reserve Bank of St. Louis Review, January/February 2010, 92(1), pp. 1-26.

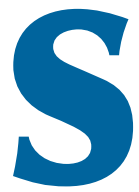

ince the U.S. economy entered its current recession in December 2007, most demographic groups and industries have seen steep job losses. By standard measures of overall labor-market performance, the news has been dire: Between 2007:Q4 and 2009:Q3, U.S. nonfarm employment fell by about 6.8 million jobs while the national unemployment rate rose from 4.8 percent to 9.6 percent.

Although the picture has been bleak overall, the recession's ill effects have not been distributed evenly across demographic groups. The difference in job losses between men and women has garnered the most attention; by 2009:Q2, men accounted for 76 percent of net job losses despite having only a slim majority (51 percent) of nonfarm employment at the start of the recession. In light of the disproportionate effects on men, some commentators in the press and elsewhere have labeled the current recession a "man-cession" or even the "Great Man-Cession."

This paper takes the different effects on men and women as a starting point and examines the employment experiences across a range of other demographic categories-marital status, race, age, and education. The purpose is to understand more about what recessions mean for people. Such information will, hopefully, give us an idea of what needs to be done to help policymakers address the effects of the current recession and better prepare for future ones.

\section{WHY LOOK AT DEMOGRAPHIC DIFFERENCES?}

The dominant explanation for the current man-cession is that it follows from differences in the severity of the recession across industries. According to Hoff Sommers (2009), men "are bearing the brunt of the current economic crisis because they predominate in manufacturing and construction, the hardest-hit sectors" and that women "are a majority in recession-resistant fields, such as education and health care.” Greg Mankiw (2009) echoes this in his blog: "[A] large part of the explanation is the sectoral mix of this

Kristie M. Engemann is a senior research associate and Howard J. Wall is a vice president and economist at the Federal Reserve Bank of St. Louis.

(C) 2010, The Federal Reserve Bank of St. Louis. The views expressed in this article are those of the author(s) and do not necessarily reflect the views of the Federal Reserve System, the Board of Governors, or the regional Federal Reserve Banks. Articles may be reprinted, reproduced, published, distributed, displayed, and transmitted in their entirety if copyright notice, author name(s), and full citation are included. Abstracts, synopses, and other derivative works may be made only with prior written permission of the Federal Reserve Bank of St. Louis. 
particular downturn in economic activity, including a significant slump in residential construction."

Job losses have indeed been steepest in the goods-producing industries-natural resources and mining, construction, and manufacturingwhich accounted for about half of total losses from 2007:Q4 to 2009:Q3. Job losses have not been the rule across all industries, however, as the education and health services sector actually saw an increase of 768,000 and the government sector added 115,000 jobs.

Despite the current interest in the phenomenon, the large difference in the relative effects of the recession on the employment of men and women is not unusual. Men always bear the brunt of job losses during recessions; and, compared with previous recessions, men have actually been bearing a smaller proportion during this one. During the five recessions between 1969 and 1991, male employment fell by an average of 3.1 percent per recession, whereas female employment actually tended to rise by 0.3 percent per recession. ${ }^{1}$ Women have a much larger presence in the workforce now than between 1969 and 1991, however, so a more relevant comparison is to the 2001 recession. In that recession, employment peaked in 2001:Q1 and bottomed out in 2003:Q3, with a total loss of a little over 2.6 million jobs. Men accounted for 78 percent of those job losses, similar to the 76 percent in the current recession. ${ }^{2}$ So, in terms of job losses, the current recession has hit men in roughly the same proportion as did the previous recession, but by a much smaller proportion than in earlier recessions.

The difference in employment between the sexes is only one of the interesting and significant differences across demographic groups. Nonfarm (or payroll) employment data are not broken down by demographic categories other than sex, however. Fortunately, the Bureau of Labor Statistics (BLS) also conducts a separate monthly "household" survey that includes several demographic categories. Employment measures from the payroll and household surveys differ in that they

1 See Goodman, Antczak, and Freeman (1993).

2 Note that data splitting nonfarm employment by sex were available only up through 2009:Q2 at the time this paper was prepared. cover different types of employment. For example, payroll employment does not include farm employment or self-employment. Nevertheless, the two employment measures capture the same broad patterns in male-female employment. In fact, by fortunate coincidence, the household survey indicates the same 76/24 split in the male/ female employment losses between 2007:Q4 and 2009:Q2 that appeared in the nonfarm employment data discussed above. From this point forward, the data we refer to come from this household survey.

The differences in household employment by sex, marital status, and race from 2007:Q4 to 2009:Q3 are illustrated by Figure 1. Whereas total employment losses amounted to 4.7 percent, male employment fell by 6.4 percent and female employment fell by 2.9 percent. Similarly, large differences in employment losses have occurred according to marital status and race: Employment of single adults fell at nearly twice the rate as it did for married adults, and white employment fell by only about two-thirds as much as black employment.

Figure 2 shows employment changes by age groups, indicating much larger-than-average employment losses for those 16 to 19, 20 to 24, and 35 to 44 years of age. In contrast, employment among those 55 years and older actually rose by 4 percent. Unsurprisingly, changes in employment across education levels also have been significant. For example, Figure 3 shows that employment of those without a high school diploma fell by 7.5 percent while employment for those with at least a bachelor's degree actually rose by 0.4 percent.

What accounts for the variation in the employment changes across these demographic groups? The oft-cited reason for the difference between the sexes is that it is a reflection of what has happened to industries. As discussed below, this is not a terribly satisfying explanation, but it does make some sense. Analogous explanations are not likely to fit the other demographic categories, however.

For example, perhaps single people are more heavily concentrated in industries hit hardest by the recession, but it is difficult to imagine why this would be so. It is much easier to imagine instead 
Figure 1

Employment Changes by Selected Demographic Categories (2007:Q4-2009:Q3)

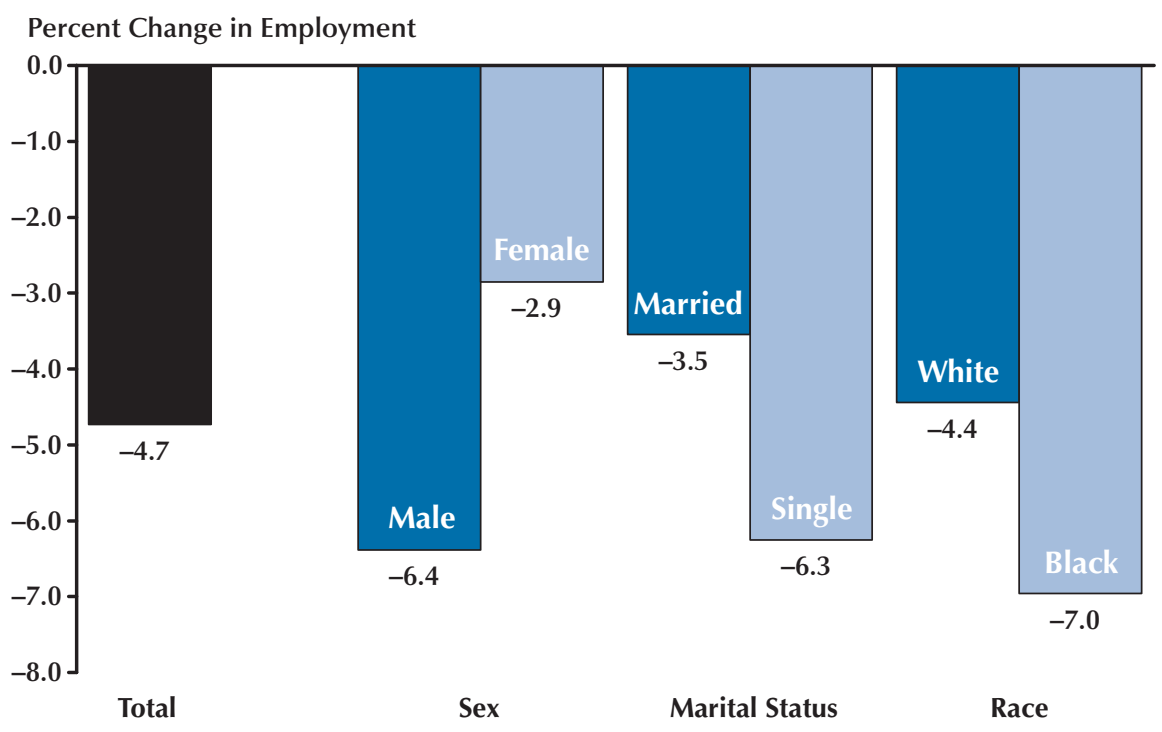

Figure 2

Employment Changes by Age Groups (2007:Q4-2009:Q3)

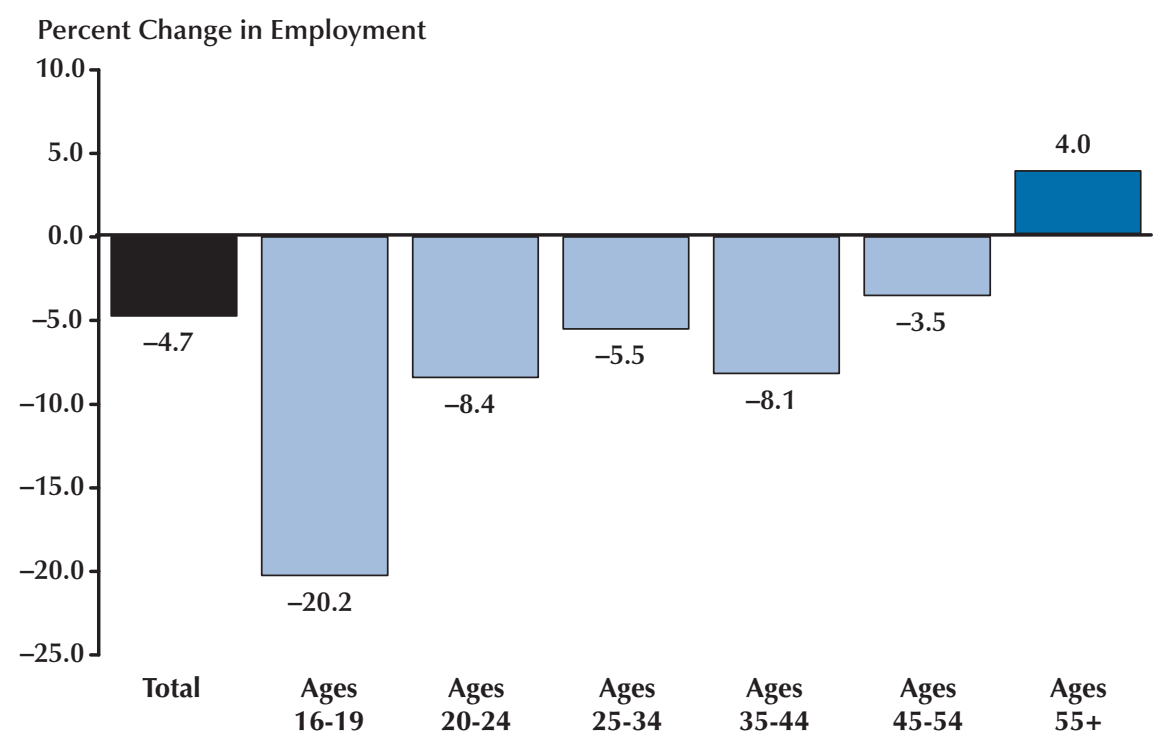


Figure 3

\section{Employment Changes by Education Levels (2007:Q4-2009:Q3)}

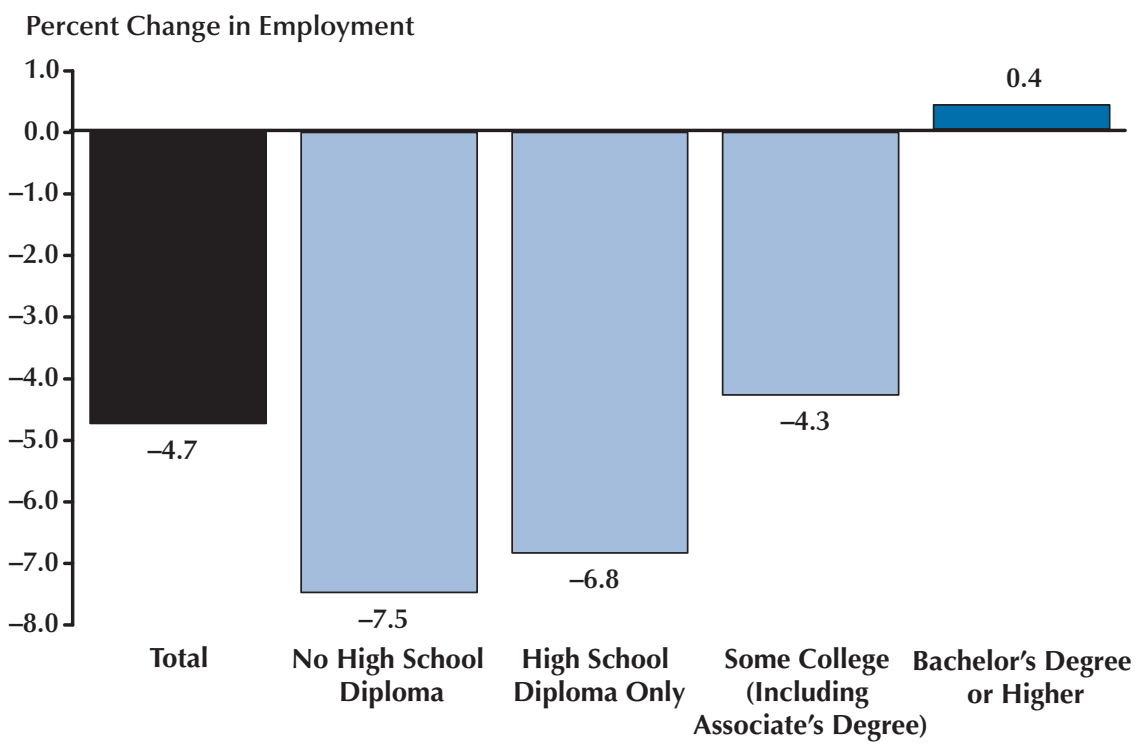

that single people might have lost proportionally more jobs because the average single person is younger and, therefore, less experienced and less educated than the average married person. Because of these differences, we would expect that, within a given industry, single people would bear disproportionate job losses.

The industry story might not even be a good causal explanation for the differences between sexes. As discussed by Wall (2009), because men have tended to be affected disproportionately across all industries, the man-cession cannot be explained by industry mix alone but must have some relation to demographic differences. For example, men are less likely than women to have finished high school, a fact that is consistent with their relative job losses.

More generally, it is not a simple matter to separate the role of industry from the role of demographics. For example, is the decrease in employment larger for manufacturing than for other industries because it experienced a larger external shock? Or was the shock the same across sectors, but job losses in manufacturing were greater because its workers, on average, have lower education levels than do workers in other sectors? Put another way, would there have been fewer job losses in manufacturing if workers in the sector had higher education levels? There are no simple answers to these questions because there is no proximate cause for what happened in manufacturing that was different from, say, professional and business services. The recession experience may have differed between the two sectors because they experienced different external shocks; or perhaps they experienced the same external shock, but the demographic differences of their workforce led to different outcomes. Most likely, some combination of the two explanations accounts for the different employment outcomes.

The questions can be turned around to refer to demographic groups: Are the different impacts of the recession across demographic groups attributable to the industries in which the groups are employed or to the differences in the groups' characteristics? Again, the most likely explanation is some combination of the two. 
WHAT ARE THE EMPLOYMENT EFFECTS OF A RECESSION?

When the word "recession" is used to describe specific periods of economic weakness, it refers most often to the official recession dates determined by the business cycle-dating committee of the National Bureau of Economic Research (NBER). When weighing their decisions whether to label a period a recession, NBER committee members take into account a wide variety of economic indicators. As a result, NBER dates for recessions tend to coincide most closely with periods in which the broadest measure of economic activity, real gross domestic product (GDP), is contracting. It used to be that NBER recession periods coincided with periods of falling employment. Beginning with the 1990-91 recession, however, this link was broken, and the economy experienced a prolonged period of job losses well after the end of the official recession. Such a so-called jobless recovery also occurred in the wake of the 2001 recession.

This disconnect between official recessions and falling employment means that it is not possible to use NBER recession dates to compare the effects of recent recessions with earlier ones. For pre-1990 recessions, one could measure the change in employment from the beginning to the end of an official recession and obtain a reasonably complete picture of the recession's employment effects. For post-1990 recessions, however, the full effects of a recession on employment were not realized until after the recession ended, and at times even began before the onset of the official recession.

Therefore, an alternative metric is needed to determine the period during which recessions affected employment. Keep in mind that using this different metric means that estimates of the effects of the current recession on the various demographic groups will differ somewhat from those in Figures 1 through 3. Nonetheless, the scale of the effects and the comparisons across categories within demographic groups are the same with either set of numbers.

Fortunately, there is a fairly straightforward statistical method for determining the timing of recessions: a Markov-switching model. Briefly, the model takes any data series, which in our case is household employment, and estimates growth rates that are typical for expansionary and recessionary phases. At the same time, the model decides for each data point the phase that best describes that period, taking into account the periods immediately prior. For example, positive employment growth that has persisted for many periods will be called an expansionary period, while negative growth that has persisted for many periods will be called a recessionary period. The tougher job is deciding on the more ambiguous periods-such as when growth is positive for one period following several periods of negative growth or when a period has middling growthso that it is not obvious if the period should be labeled part of a recession. We will leave it to the model to decide these tough questions so that there will be a consistent application across recessions. ${ }^{3}$

Appendix A provides the estimated periods for which household employment was in recession surrounding each of the six official recessions since 1974. Figure A1 compares the growth rate of household employment with the official NBER recession dates, showing that employment growth first dipped below zero in early 2007, months before the start of the official recession, and remained weak thereafter. As a consequence, the last three quarters of 2007 are classified as recessionary, meaning that household employment was in recession three quarters earlier than the start of the official recession. ${ }^{4}$

\section{TOTAL EFFECTS OF RECESSIONS ON TOTAL EMPLOYMENT}

Once the timing of official recessions is disentangled from the periods during which they are

\footnotetext{
3 See Owyang, Piger, and Wall (2008) for a technical description of the statistical methodology and for results using aggregate payroll employment. A quarter is designated as recessionary if the probability of recession exceeds 50 percent.

4 Note that the disjoint between official recessions and household employment recessions is not as severe as might have been expected. This is because household employment tends to recover earlier than payroll employment, which is the measure most often used in discussions of jobless recoveries.
} 
Table 1

Total Percent Effects of Recessions on Employment

\begin{tabular}{lccc} 
Recession & Employment Change & Forgone Employment & Total Effect \\
\hline $1974-75$ & -2.0 & -1.9 & -3.9 \\
1980 & -1.0 & -1.3 & -2.2 \\
$1981-82$ & -1.7 & -4.4 & -6.0 \\
$1990-91$ & -1.2 & -2.3 & -3.5 \\
2001 & -1.2 & -1.3 & -2.5 \\
$2007-09$ & -4.6 & -3.3 & -7.9 \\
Average & -1.9 & -2.4 & -4.3
\end{tabular}

NOTE: The recession dates and the employment data are for the household employment series produced by the BLS.

affecting employment, the total employment changes related to the current recession can be calculated and compared with those of earlier recessions. The percent changes in total employment during each of the estimated recession periods are provided in the second column of Table 1. The most notable result in the column is that the 4.6 percent employment loss from the current recession dwarfs those of the other five, which were in the 1 to 2 percent range.

Typically, the effects of a recession on employment are seen as simply the difference between the levels of employment at the start and end of a recessionary period, as in the second column of Table 1. This assumes, though, that there would have been zero employment growth even if there had been no recession. However, a recession not only causes a drop in employment from the prerecession level, it also prevents employment growth that would have occurred. This "forgone" employment is also an effect of the recession and needs to be accounted for in an analysis of the recession's total effects on employment. Figure 4 provides a diagrammatic explanation of the total costs of the recession on employment.

In the figure, the solid line is the actual path that employment followed over time, including a recession with falling employment. The dotted line is the path that employment would have followed if the recession had not occurred. This is an extremely stylized diagram that assumes that employment growth is constant and positive dur- ing expansionary periods and constant and negative during recessions. The direct change in the level of employment is C-B, the difference between the levels of employment at the end and at the beginning of the recession. If the recession had not occurred, the level of employment would have continued to rise and would have reached level A when the recession ended. Thus, the total effect of the recession on employment is C-A, which includes forgone employment (B-A) and the change in employment (C-B).

The most straightforward way to account for forgone employment is to assume that employment would have grown at some typical rate if the recession had not occurred. We also must account for differences in growth rates before and after the mid-1980s, when the so-called Great Moderation meant significantly less variability in the growth of a wide range of economic variables. Specifically, we assume as relevant that, during a recession, employment would have grown at its median growth rate for the periods 1972-84 and 1985-2009.

The third column of Table 1 shows estimates of the employment growth that was forgone during each of the six recessions, which for the current recession is not particularly onerous. Although forgone employment has been above average, it is much smaller than it was for the 1981-82 recession, primarily because median employment growth before 1985 was higher than after 1985. Nonetheless, by combining forgone employment with the employment decline, the total effect of 


\section{Figure 4}

\section{The Two Effects of Recession on Employment}

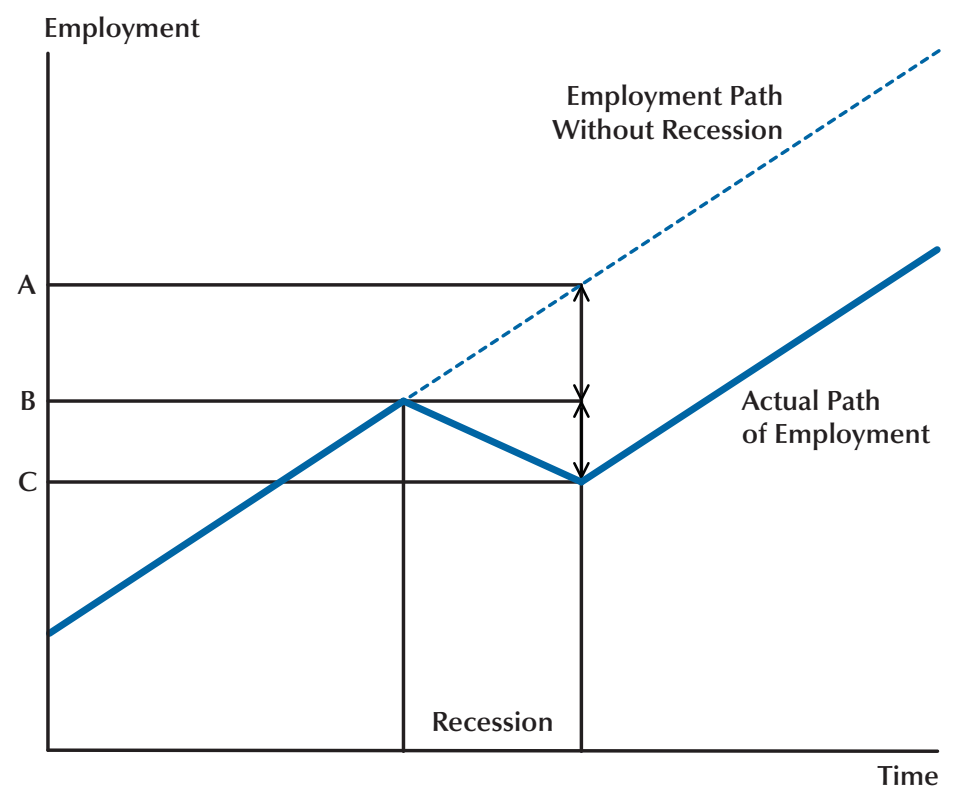

the current recession is the highest among the six recessions, with only the 1981-82 recession coming close.

In the subsequent section, a similar exercise is performed for a variety of demographic categories. Specifically, the exercise shows the effects of the current recession by sex and compares them with previous recessions. It then does this, in turn, for marital status, race, and age, with extra attention paid to the differences between men and women for each category.

\section{RECESSIONS ACROSS DEMOGRAPHIC CATEGORIES}

When calculating forgone employment, one must also consider the sometimes large differences in typical growth across demographic categories. For reference, the different employment trends are summarized in Appendix B, which provides employment-to-population ratios for 1972-2009 for the demographic categories examined below. As with total employment in the previous section, we assume, as relevant, that, during a recession employment for each demographic category would have grown at its median growth rate for the periods 1972-84 and 1985-2009 (see Appendix C). ${ }^{5}$

\section{Sex}

As already mentioned, men always bear the brunt of employment losses during recessions, and the current recession has been no different. This is true whether one looks at payroll employment, as earlier studies have, or at household employment, as this study does. As reported in Table 2, male household employment has fallen 2.46 times the rate that female employment has (-6.4 percent vs. -2.6 percent) during the current recession. Looking at earlier recessions, it is clear that the current one is actually in the lower half in terms of the relative effects on men. During the two recessions in the 1980s, male and female

5 This breakpoint will also take account of the significant decrease in female employment growth that occurred after 1990 as the rapid increases in female labor-force participation wound down. 
Table 2

Percent Effects of Recessions on Employment

\begin{tabular}{lccr} 
Recession & Men & Women & Men/Women \\
\hline $1974-75$ & -2.8 & -0.9 & 3.10 \\
1980 & -1.7 & 0.0 & -58.12 \\
$1981-82$ & -3.3 & 0.5 & -6.76 \\
$1990-91$ & -2.0 & -0.3 & 6.90 \\
2001 & -1.2 & -1.1 & 1.13 \\
$2007-09$ & -6.4 & -2.6 & 2.46 \\
Average & -2.9 & -0.7 & 3.99
\end{tabular}

NOTE: The recession dates and the employment data are for the household employment series produced by the BLS.

employment moved in opposite directions, while during the 1990-91 recession, male employment fell nearly seven times the rate that female employment did. The 1974-75 recession was somewhat comparable to the current recession in the relative employment loss for men, but the 2001 recession saw male employment fall only slightly more than female employment.

The story of the current recession changes a great deal when forgone employment is considered. As reported in Figure 5, male forgone employment has been only 62 percent that of women. This is because employment growth for women has tended to be higher than that for men during the entire sample period-meaning that, for every quarter of recession, more female than male employment is forgone. Adding the two effects together reveals that men as a whole have still borne a much larger effect of the recession, but it is 1.33 times the effect for women rather than 2.46 times, as suggested by the employment changes alone.

Now that we know the total employment effects of the current recession, how does it compare with earlier ones? Has it been the Great Man-Cession? Figure 6 shows the total effects of the six recessions since 1974 on male and female employment, along with the relative effect for men and women. For both sexes, this has been the most costly recession in terms of employment. Male employment is 8.9 percent lower than it would have been without a recession, which is rivaled only by the total effect of the 1981-82 recession. For women, the current recession is somewhat similar to the 1981-82 recession, when female employment actually rose (recall Table 2). However, because female employment growth was much higher before than after 1985, they experienced a comparatively higher percentage of forgone employment during the 1981-82 recession. ${ }^{6}$

The male-to-female ratio for the current recession, 1.33, is surpassed only by the 1980 recession and is much higher than for all other recessions. So, even though it's not quite the Great Man-Cession, it's still been relatively more severe for men than is usual. Interestingly, the estimates also indicate that the total effects of the 2001 recession were actually higher for women than for men. Recall from Table 2 that employment losses for men and women did not differ by much, so the higher forgone employment for women means a higher total effect.

\section{Marital Status}

Over the course of the current recession, the employment of married people has fallen at 76 percent of the rate that employment of single people has fallen (Figure 7). Married employment fell by 4 percent while single employment fell by 5.3 percent. Because single employment has

\footnotetext{
6 A recent paper by DiCecio et al. (2008) reviews changes in laborforce participation, separating trends from the changes due to economic conditions.
} 
Figure 5

Total Effects of 2007-09 Recession: Men versus Women

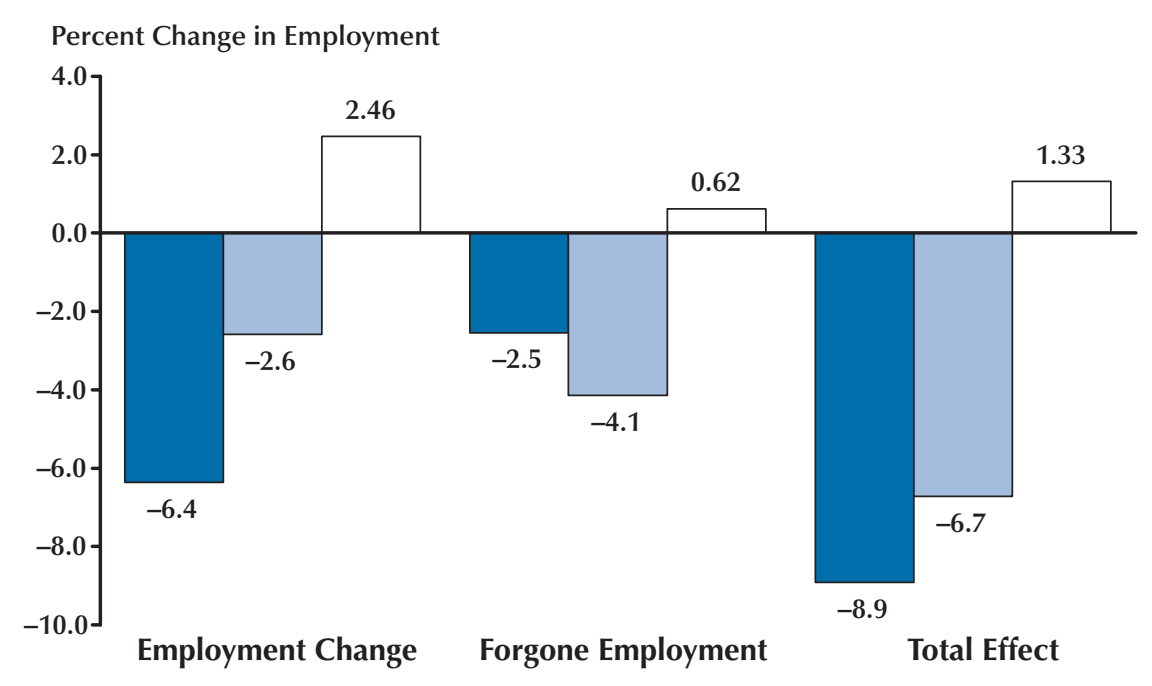

$\square$ Men $\square$ Women $\square$ Men/Women

Figure 6

Total Effects of Recessions: Men versus Women

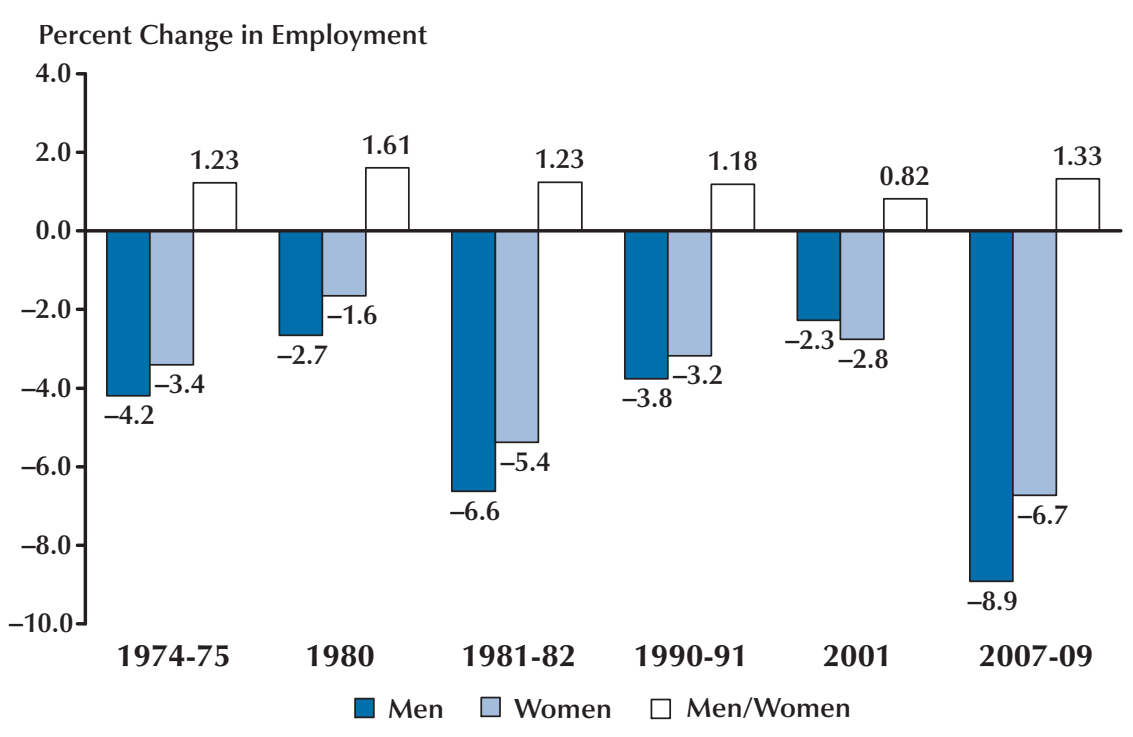


Figure 7

Total Effects of 2007-09 Recession: Married versus Single

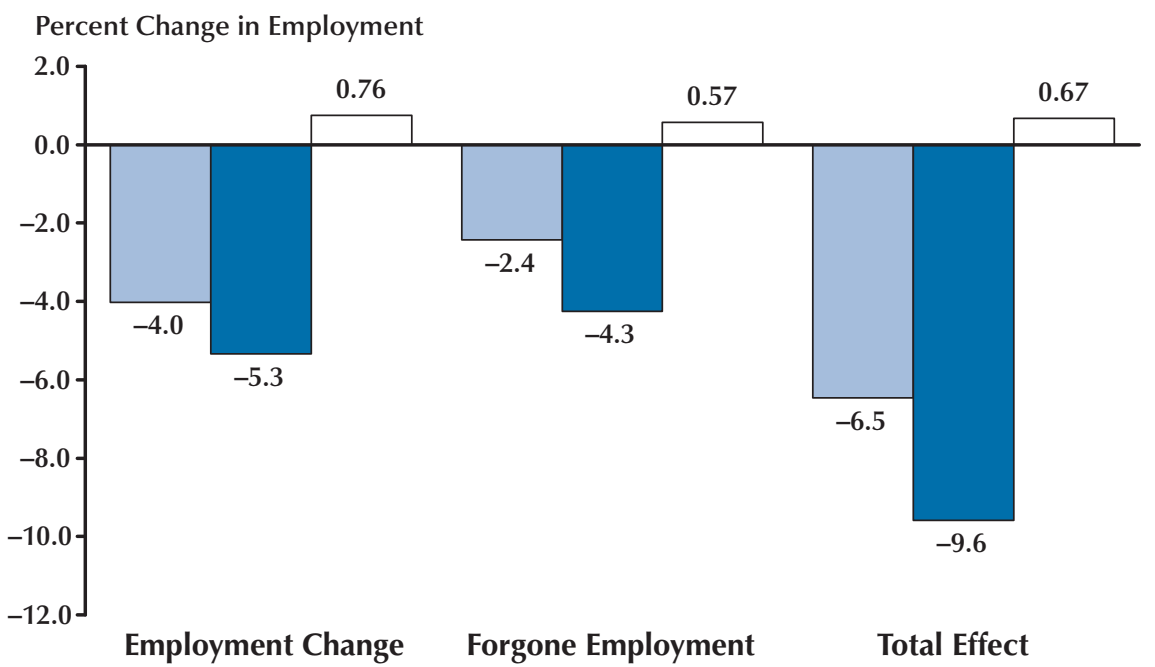

$\square$ Married $\square$ Single $\square$ Married/Single

\section{Figure 8}

\section{Total Effects of Recessions: Married versus Single}

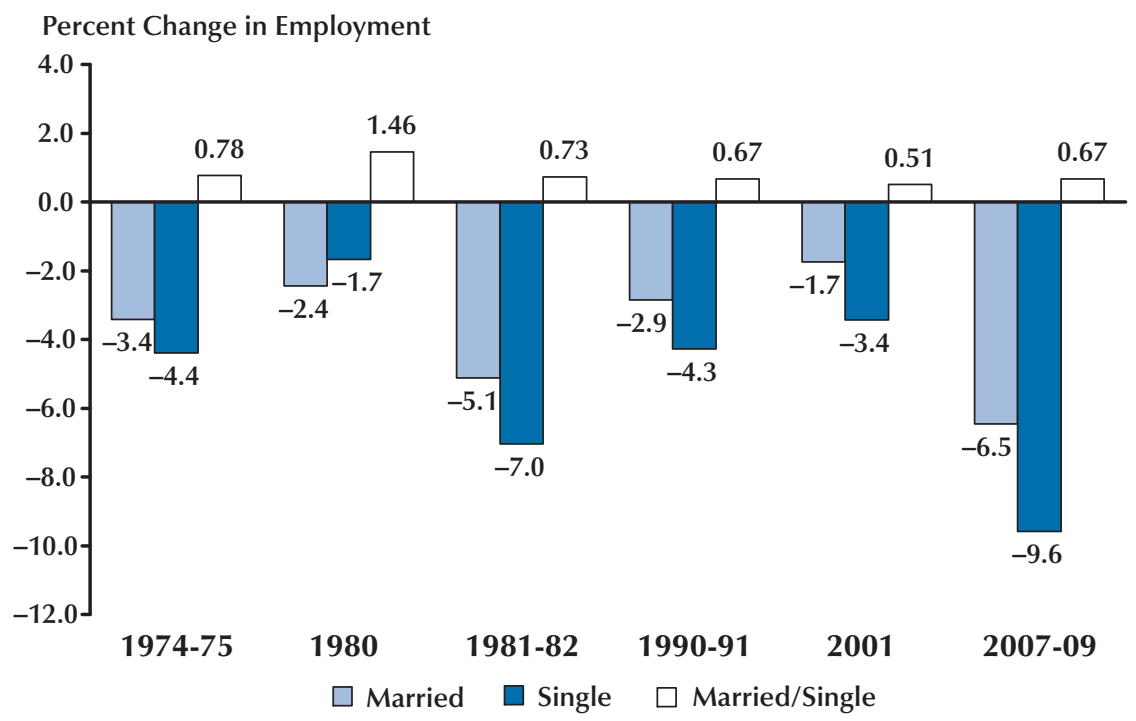




\section{Figure 9}

\section{Total Effects of 2007-09 Recession: Marital Status and Men versus Women}

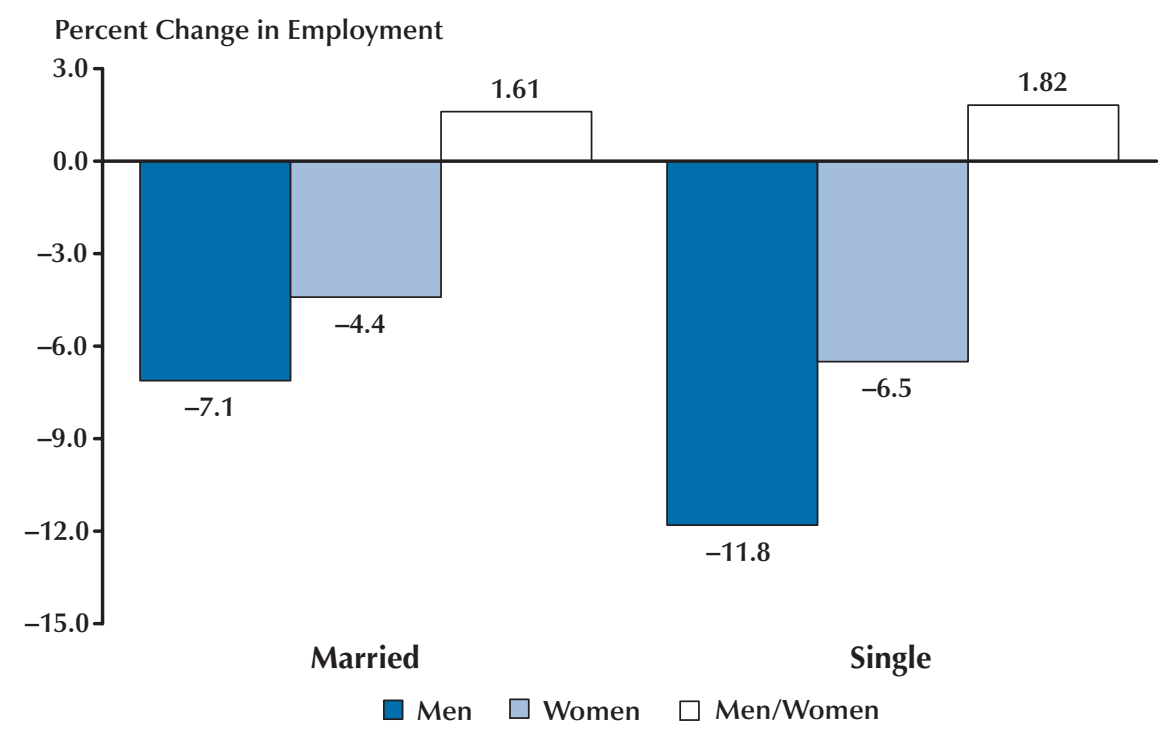

tended to grow much faster than married employment since 1985, the forgone employment for singles during the recession has been much larger. Adding up the two effects, the total effect of the recession for married people has been 67 percent as large as the total effect for single people.

The relative effects of this recession on married and single workers are typical of those for the previous five recessions (Figure 8). Single people have almost always borne a greater total effect, although, because the median employment growth for singles is lower than it was before 1985, the forgone employment for singles was relatively less important for the past two recessions. With the exception of the 1980 recession, married people bore between 50 and 80 percent of the total effect that single people did. For the 1980 recession, employment for singles, particularly single women, was higher at the end of the recession than at the beginning. As we have seen, that recession was really one that hit men the hardest relative to other categories.

An interesting difference is found in the comparison of men and women in the married and single categories (Figure 9). In the current reces- sion, married men and women saw smaller job losses than did their single counterparts, meaning that married women saw the smallest reduction in employment of the four groups. In part, this can be explained by what has been called the "added-worker effect." 7 According to this effect, some married women enter the labor force during recessions following their husbands' job losses. The added-worker effect can account for the fact that the number of women in the labor force, either employed or looking for employment, has actually risen during the current recession, whereas the male labor force has fallen.

Another explanation for the difference between married and single people is that married people are more likely to have children to support and are, therefore, more likely to take a new job at lower pay after they lose a job. Also, many of the differences for marital status are reflections of other demographic differences that make them more likely to be affected by a recession: Compared with married people, single people tend to

7 See, for example, Stephens (2002). DeRiviere (2008) has estimated the size of a related effect called the "pin-money" hypothesis. 
be younger (i.e., have less work experience) and have lower education levels.

\section{White and Black}

As with all demographic groups, the differences across racial categories are intertwined with differences across other categories as well. For example, black men, for whom average education is lower than for black women or whites, saw the largest decrease in employment. Black women, on the other hand, have seen the most forgone employment of any of these sex-race categories. Underlying these differences is the longterm trend of women, especially black women, becoming more likely to be employed (see Appendices B and C).

The white-black employment effects of the current recession are illustrated by Figure 10, which indicates that white employment has fallen at 58 percent of the rate that black employment has ( -4.4 percent vs. -7.5 percent). Because black employment has tended to grow faster than white employment, white forgone employment has been only 79 percent of that for blacks.

Figure 11 shows the relative total effects of the past six recessions on black and white employment. Recent recessions have actually tended to affect black employment relatively more than they used to, even as blacks have become more successful in the labor market. For the past three recessions, the ratio of white-to-black total effects has been between 0.65 and 0.74 , after it had been above 1 for the two recessions of the 1980s, indicating that white employment had been more adversely affected. In part, this change over time is because the gap between white and black employment growth has reversed.

It is worth breaking out the two employment effects (employment change and forgone employment) for all six recessions to see how the whiteto-black ratios have changed over time (Figure 12). Before 1985, white employment grew at a median rate of 2.5 percent per year, whereas the analogous number for black employment was 2.1 percent. Thus, there was more forgone white employment for each quarter of recession. Since 1985, however, median white employment growth has fallen by half, whereas median black employment growth has fallen by only one quarter. The ratio of direct employment changes has also fallen over time, meaning that the direct employment change used to be relatively smaller for blacks than it has become. (The 1974-75 recession, however, hit black employment much harder than white employment.) As a consequence, blacks tend to bear a relatively larger burden during recessions now than they used to.

In a sense, the recent success in labor markets has made the total effects of recessions on blacks greater than in the past. As already discussed, black employment has been growing faster than white employment, so each quarter of recession means a greater loss of employment for blacks. Also, because blacks now have higher participation in the labor market than in the past and their education and work experience still lags those of whites, more blacks are vulnerable to the effects of recession than had been the case earlier.

We have alluded to white/black differences in the relative effects of recessions on men and women. This is illustrated for the current recession by Figure 13, which shows that the total effect on white men and women is smaller than that on black men and women, respectively. Also, the total effect on white men is 59 percent greater than that on white women, while the total effect on black men is 18 percent higher than that on black women. This difference is because black women have seen a much larger decline in employment than have white women ( -5.3 percent vs. -2.3 percent) while also seeing more forgone employment because black women's median growth rate is nearly twice that of white women. Just as described for black employment overall, this story is really a side effect of the labor market success of black women, who have seen rapid employment growth relative to black men and white women.

\section{White and Other}

The race category "Other" captures all who are neither white nor black and has become an increasingly important category in the labor market: In 1972, the Other category accounted for 1.2 percent of total employment, but by 2009:Q3 


\section{TOTAL EFFECTS OF 2007-09 RECESSION: HISPANICS}

Over the course of the current recession, Hispanic employment has not fallen by as much as overall employment ( -3.4 percent vs. -4.6 percent), and, for both men and women, Hispanic employment has fallen by at least 1 percentage point less than has overall employment. On the other hand, because Hispanic employment has tended to grow at almost twice the rate of overall employment, these simple employment changes do not capture the whole story. Specifically, whereas overall forgone employment has been 3.3 percent, Hispanic forgone employment has been 6.1 percent, with similar numbers for men and women. In total, the recession has hit Hispanic employment relatively hard, resulting in employment that is 9.5 percent lower than it would have been if the recession had not occurred. As with overall employment, the effects of the recession have been more severe for Hispanic men, who have borne about a 40 percent larger total effect than have Hispanic women. For Hispanics, however, the difference between men and women comes from the employment change rather than forgone employment. ${ }^{1}$

\section{Figure}

\section{Total Effects of 2007-09 Recession: Hispanics}

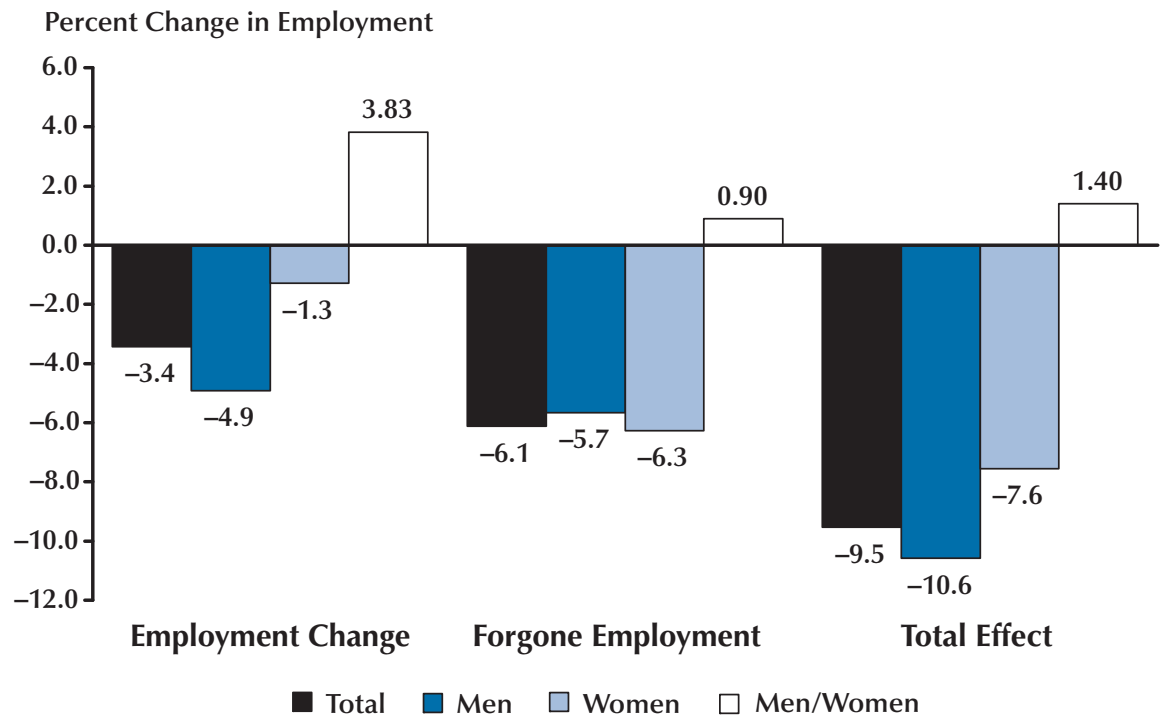

\footnotetext{
1 Note that it is not possible to do simple comparisons of the Hispanic experience across recessions because the data have been subject to extremely large spikes following new estimates of the Hispanic population.
} 
Figure 10

Total Effects of 2007-09 Recession: White versus Black

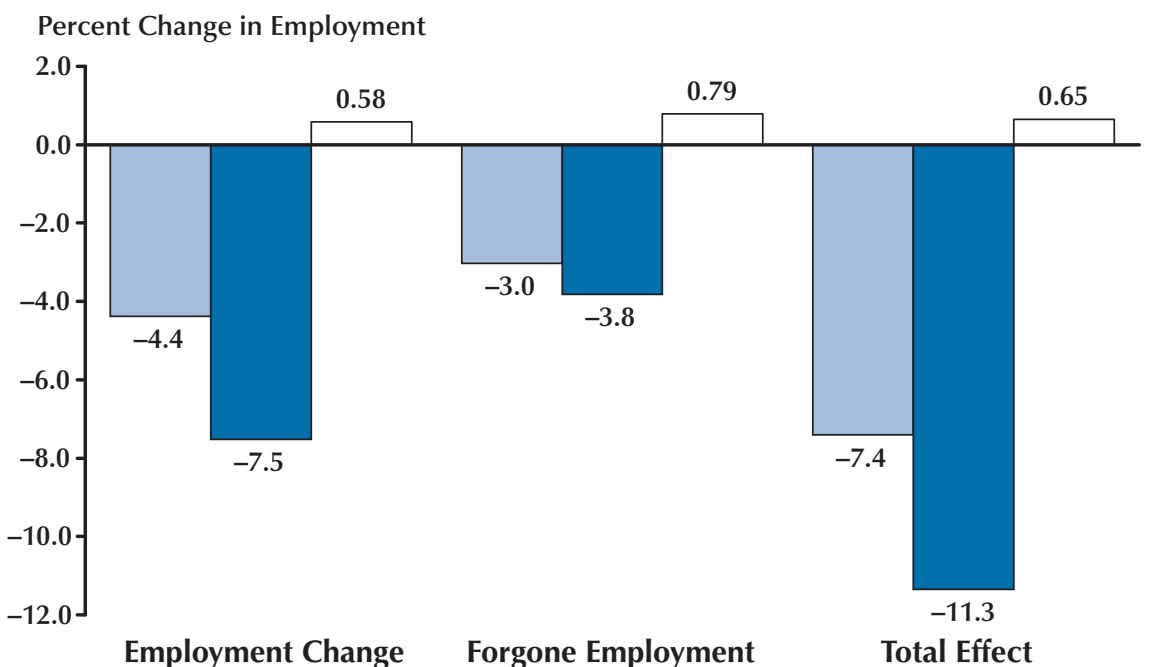

$\square$ White $\square$ Black $\square$ White/Black

\section{Figure 11}

\section{Total Effects of Recessions: White versus Black}

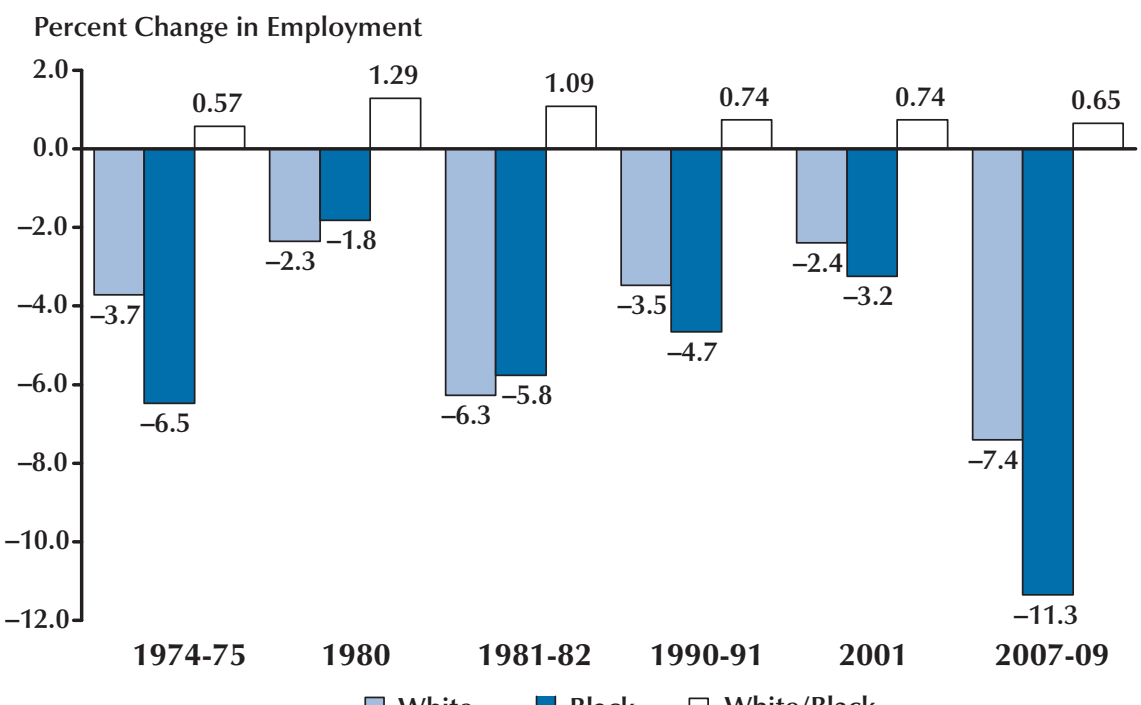

$\square$ White $\quad \square$ Black $\square$ White/Black 


\section{Figure 12}

\section{The Two Employment Effects of Recessions: White versus Black}

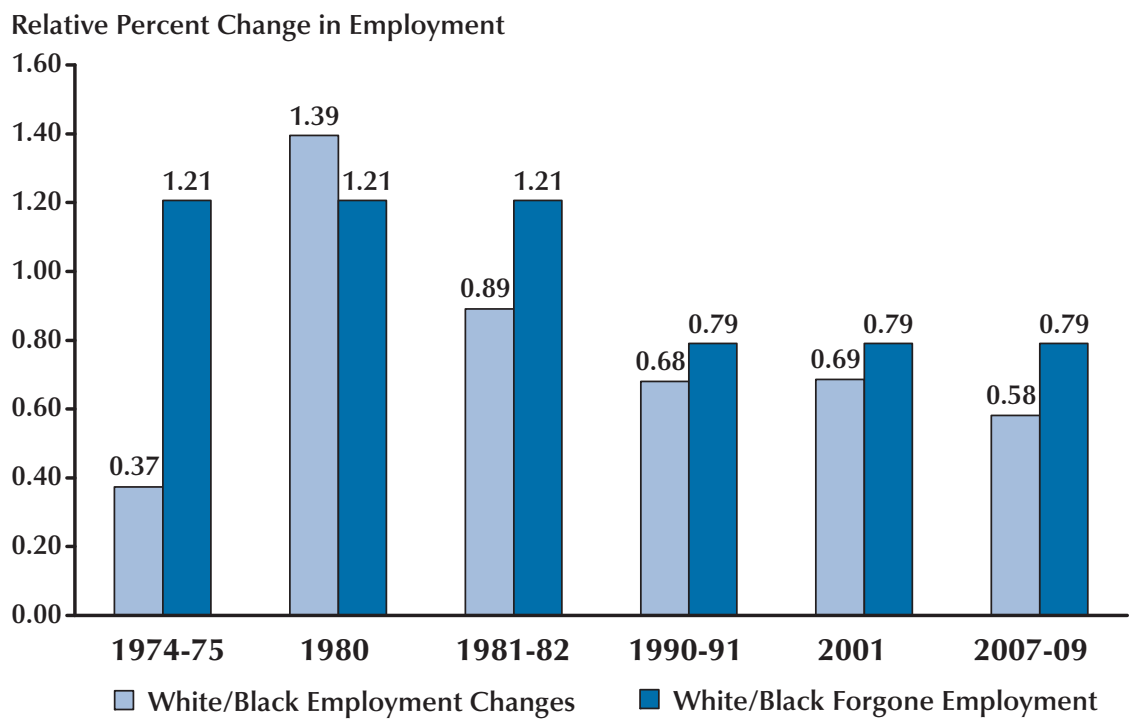

\section{Figure 13}

Total Effects of 2007-09 Recession: White and Black and Men versus Women

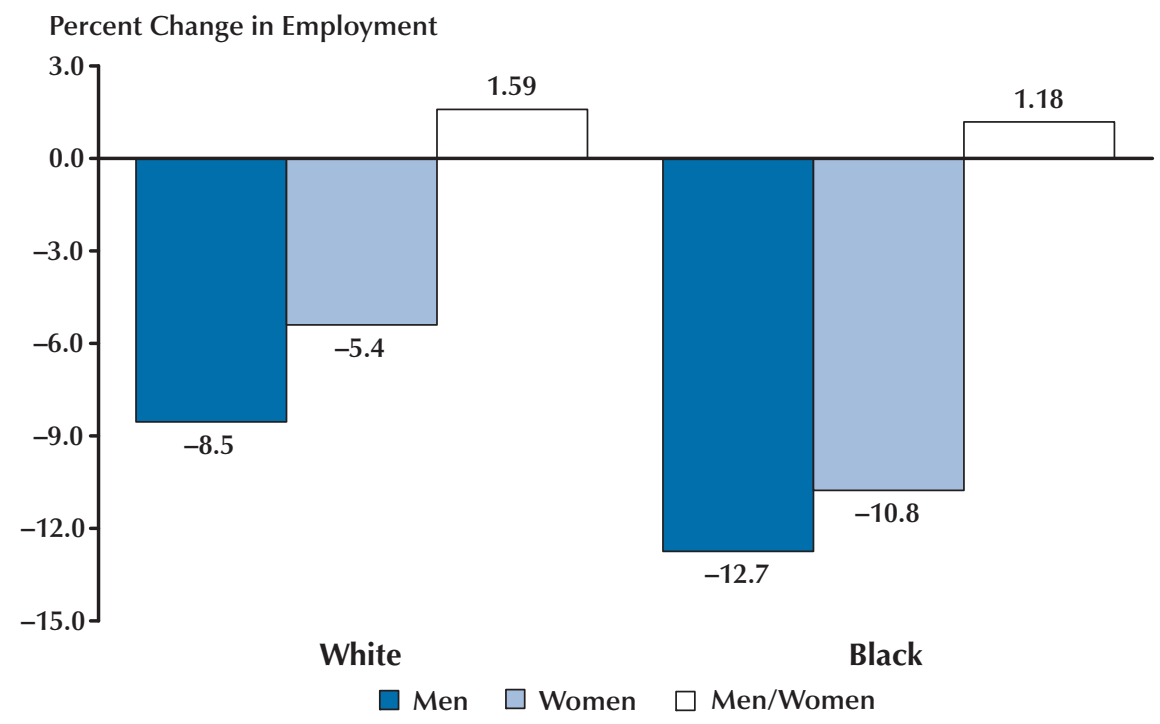


Figure 14

Total Effects of 2007-09 Recession: White versus Other

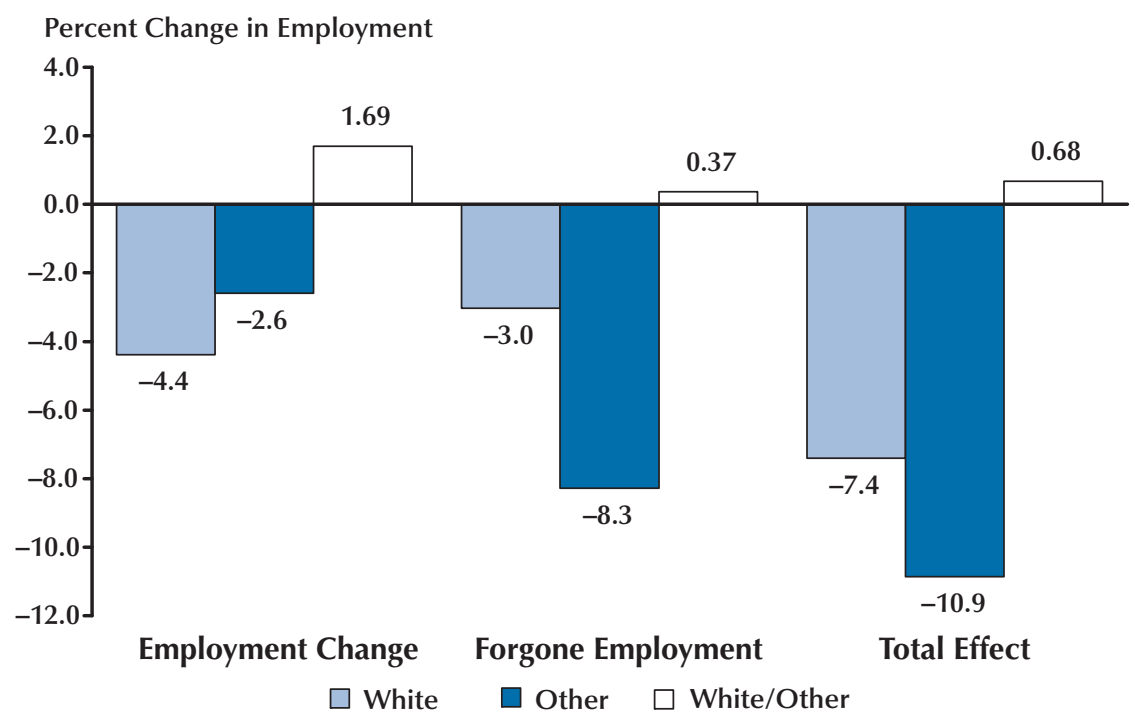

Figure 15

Total Effects of Recessions: White versus Other

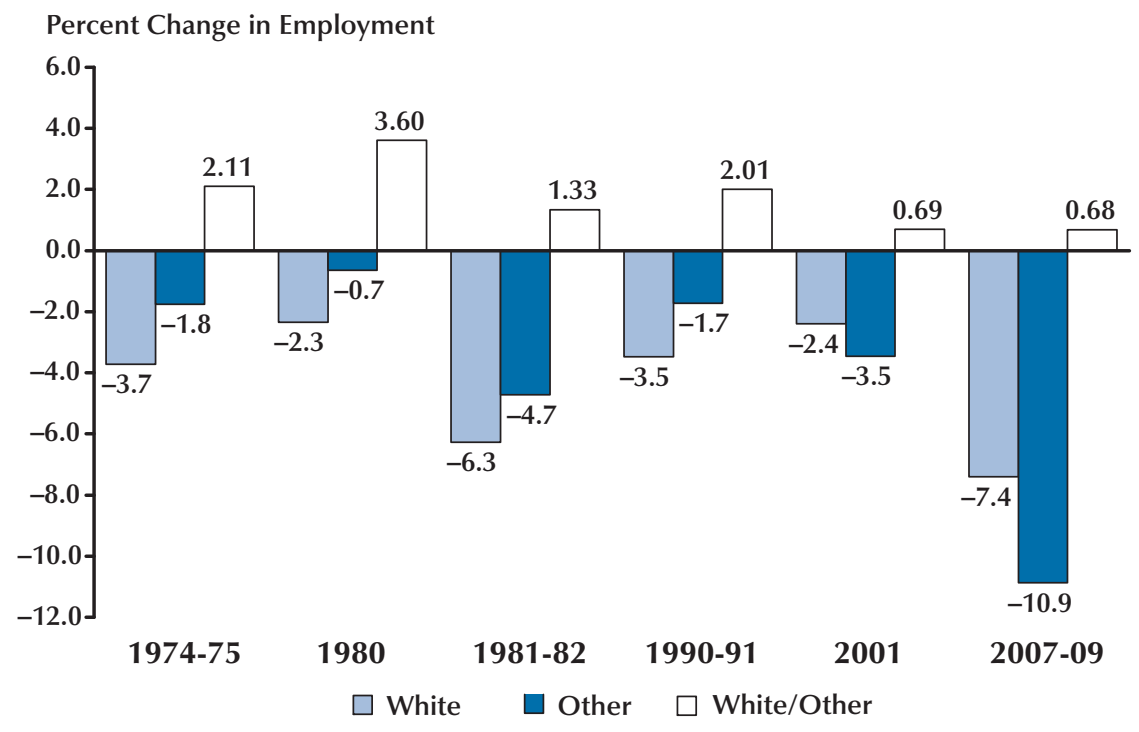




\section{Figure 16}

\section{Total Effects of 2007-09 Recession: White and Other and Men versus Women}

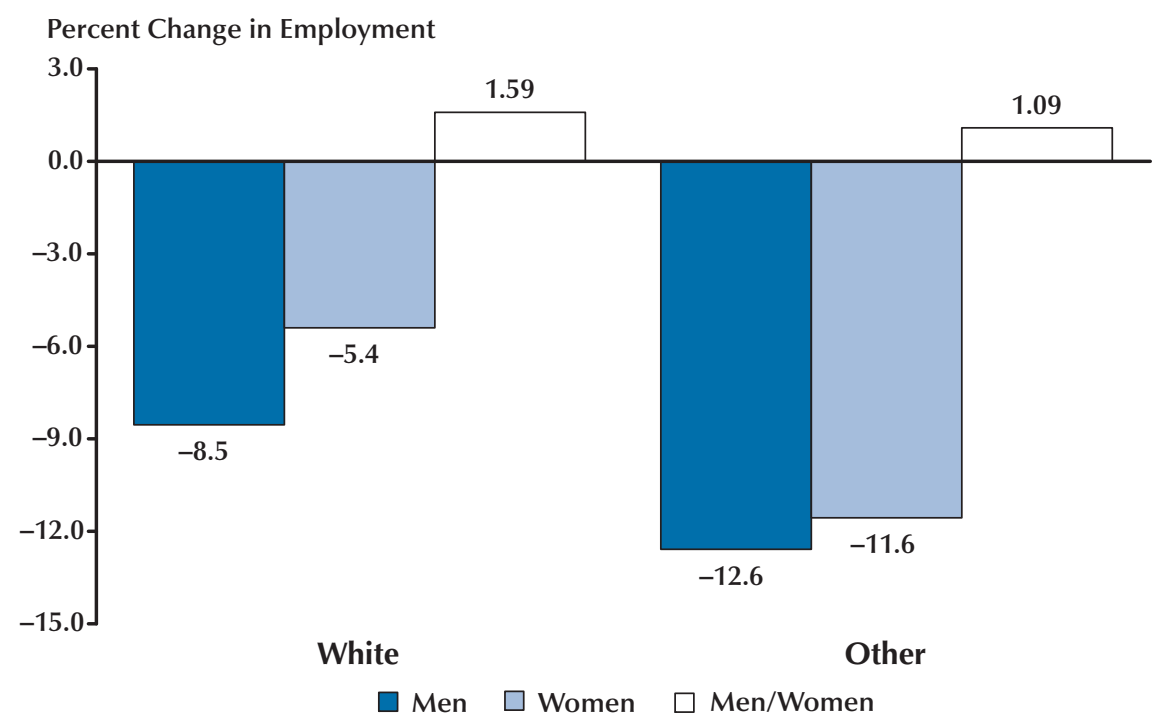

it had risen to 7 percent. ${ }^{8}$ Over that period, the composition of the category changed a great deal, reflecting large influxes of immigrants from China, India, and other Asian countries. In 2007, the average education level of the group was much higher than for the population as a whole, which is reflected in the group's employment performance during the recession.

As depicted by Figure 14, the Other group has seen a drop in employment about half that of whites. On the other hand, because median employment growth for the group is nearly three times that of whites, the group's forgone employment during the current recession has been almost triple that of whites. In total then, employment for the group is estimated to be 10.9 percent lower than if the recession had not occurred. This effect is of roughly the same magnitude as for blacks, but for very different reasons. The bulk of the effect for blacks was from a drop in employment, whereas for people in the Other category the bulk

\footnotetext{
8 At the start of 1972, the white and black shares of employment were 89.4 percent and 9.4 percent, respectively. By 2009:Q3 the shares were 82.3 percent and 10.7 percent, respectively.
}

of the effect was from forgone employment.

It has only been in the past two recessions that the Other category experienced a larger total effect than did whites (Figure 15). During the four earlier recessions, employment of this group rose by between 3.3 percent and 9.3 percent, whereas negative employment changes are the current norm. So, despite large forgone employment during recessions, the total effects of recessions on the group used to be relatively small.

Unlike the other two race categories, men and women in the Other category have seen similar total effects from the current recession (Figure 16). Just as with the total effects over time, this equality of the sexes is a recent phenomenon. For example, for the earliest three recessions in our sample period, men saw much larger negative total effects during recessions.

\section{Age Groups}

The different effects of the current recession are stark when they are broken down by age groups. Teen employment has fallen by 23.8 percent during the recession, whereas employment of those 55 years and older has risen by 7.4 percent 


\section{Figure 17}

\section{Total Effects of 2007-09 Recession: Age Groups}

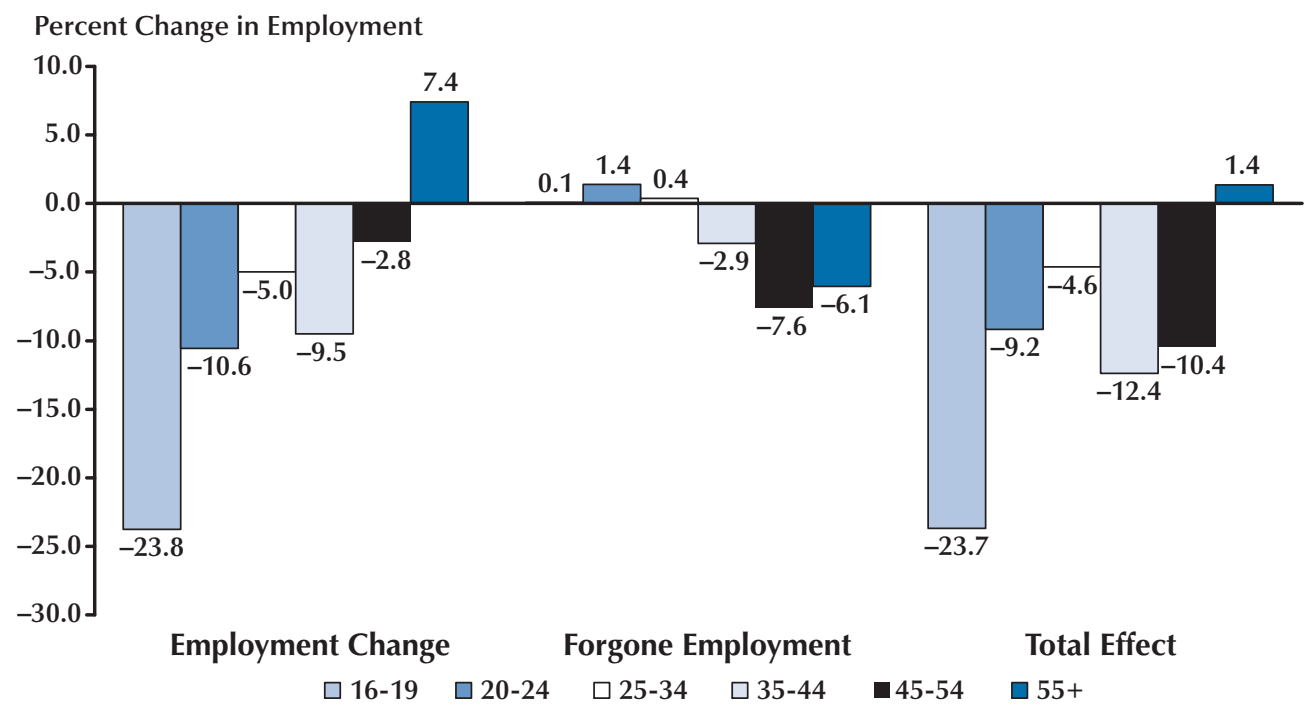

(Figure 17). The 20- to 24-year and 35- to 44-year age groups also have experienced significant employment declines, while the employment drop for the 45- to 54-year age group has been relatively minor.

One reason the 55-plus age group has seen increased employment during the current recession is the effect of the recession on the decision to retire. A dominant feature of the recession has been a significant collapse of stock prices and the resulting devaluation of many people's retirement savings. So, instead of retiring, large numbers of this age group have elected to remain employed, thereby suppressing the normal effect that the recession would have had. In fact, employment of this age group was higher than it would have been without a recession: It grew by 7.4 percent during the recession, but, without a recession, it would have grown by 6.1 percent. This leaves a total effect of an increase in employment of 1.4 percent. From these numbers, it is not possible to determine the number of people who were pushed into employment because of the collapse of retirement savings. The push effect is something greater than 1.4 percent because that number is the push effect minus the decrease in the demand for these workers that resulted from the recession.

At the other end of the age spectrum, the total effect on employment for the 16- to 19-year group was the same as its employment change. Forgone employment was almost zero because effectively there has been no trend employment growth for this age group. The share of the population of this group that is employed has been falling steadily over time, even when the economy was not in recession (see Appendix B).

As the group with the lowest average education and the least experience, it is not surprising that teenagers have borne a much bigger-thanaverage burden of the recession. We need to be careful, however, before attributing the entire change in employment to the recession. The federal minimum wage rose in the middle of the recession in 2008 and would have had its largest negative employment impacts on the two youngest age groups. A majority of those working at or below the minimum wage in 2008 were younger than 25 years, and almost half of those were teenagers.

The age breakdown also provides interesting insights into the nature of the relatively large effect 


\section{Figure 18}

\section{Total Effects of 2007-09 Recession: Age Groups and Men versus Women}

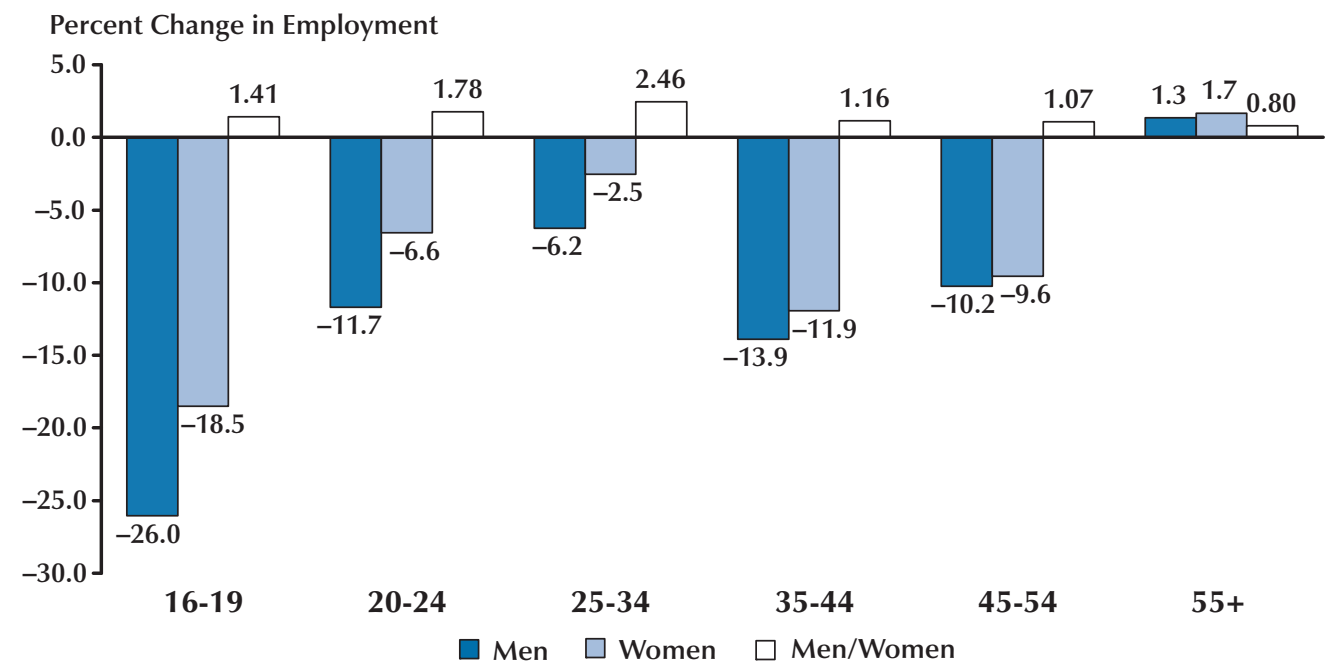

that the recession has had on men. The three oldest groups saw relatively similar effects on men and women (Figure 18). For the 25- to 34-year age group, on the other hand, the total effect on men has been 2.46 times the total effect on women. Therefore, any explanation of the man-cession must include a discussion of the role of age.

\section{THE ROLE OF EDUCATIONAL ATTAINMENT}

The final demographic category is educational attainment, which, because of its importance as a causal factor in the results across all other categories, warrants its own section. Figure 19 breaks down the effect of the current recession according to educational attainment. Keep in mind that the employment data by educational attainment include only those aged 25 and older. This gives a better idea of the employment effects once people achieve their highest education level.

The employment change during the recession has been greatest for those without a high school diploma, followed by those who have completed high school but have not attended any college.
Employment for those with some college fell slightly, while employment for those with a bachelor's degree actually rose during the recession. Because trends across these groups differ a great deal, so do the estimates of their forgone employment. Specifically, employment for those without a high school diploma has been trending down for many years, so part of the decrease in employment during the recession would have occurred anyway. Correcting for this, the total effect of the recession on the employment of those without a high school diploma has been a drop of 13.2 percent. Above-average effects have also been experienced by those with a high school diploma but no college. The total effect on those with at least a bachelor's degree has also been higher than average because forgone employment for this group was the highest among the four categories.

Using Figure 20, it is possible to map the results for educational attainment onto the results across other demographic groups. Specifically, recall that the effect of the current recession on men has been 1.33 times its effect on women. Figure 20 shows that men are less likely to have completed high school, whereas women are much more likely to have some college (particularly an 
Figure 19

Total Effects of 2007-09 Recession: Education Level

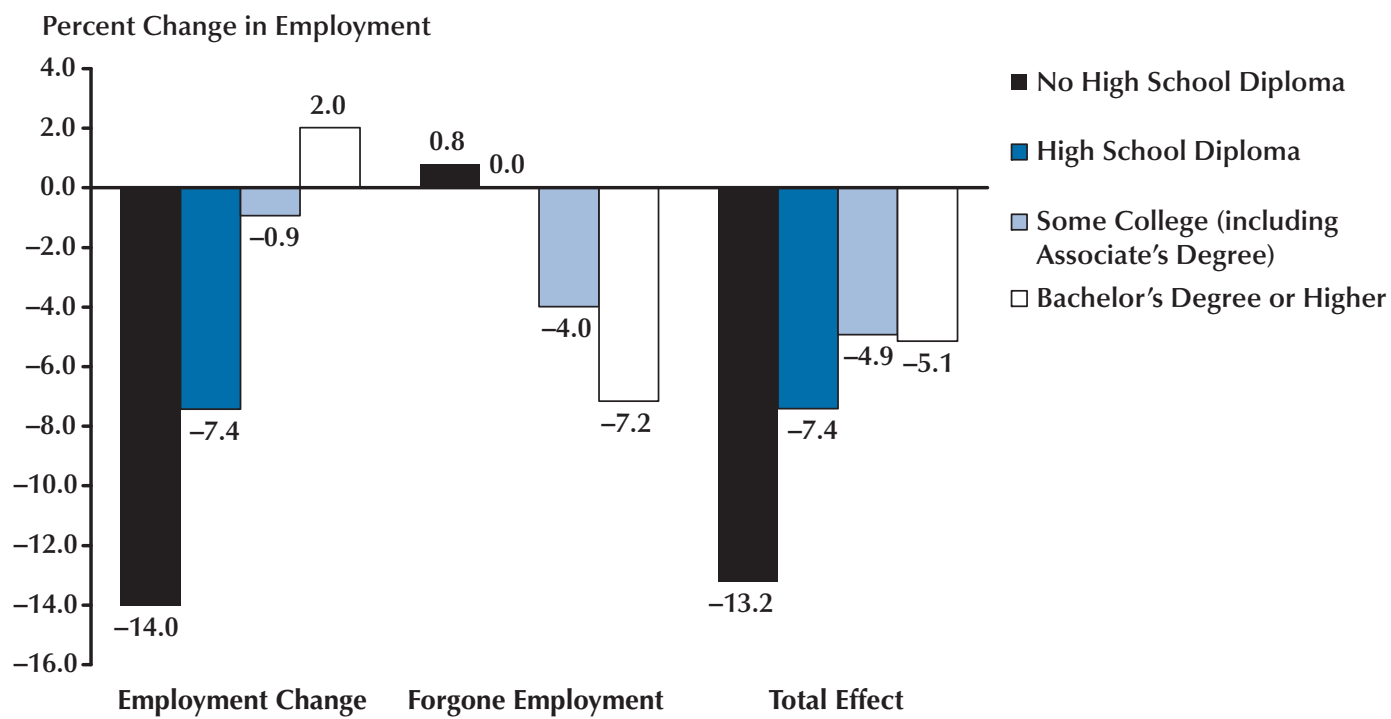

associate's degree in the nearly recession-proof nursing profession). Recall also that the effect of the recession on single people has been much greater than it has been on married people. From Figure 20, we can see that single people 25 years and older are much more likely to not have a high school diploma or to have only a high school diploma. They are also much less likely to have a bachelor's degree.

Educational attainment across racial categories maps just as easily onto the employment effects described in previous sections. Relative to white employment, the effect of the current recession on black employment is larger primarily because of larger direct decreases in employment. In contrast, the effect on the employment of those in the Other category is also larger than for whites, but this is primarily because of higher forgone employment. Relative to whites, blacks are much less likely to have a bachelor's degree and more likely to have a high school diploma or less (Figure 21). For those in the Other category, those 25 years and older are much more likely to have a bachelor's degree or higher.

It is not possible to conclude from the analysis here that educational attainment is the primary determinant of the extent to which a recession affects employment across demographic groups. Other factors-such as the industries in which people tend to be employed, job experience, cultural differences, etc.-clearly matter, also.

Nevertheless, any discussion of the effects of a recession across demographic groups should have educational attainment as one of the first, if not the first, factor that is considered. 


\section{Figure 20}

Educational Attainment, 25 Years and Older: 2007 (Difference from the Total: Sex and Marital Status)

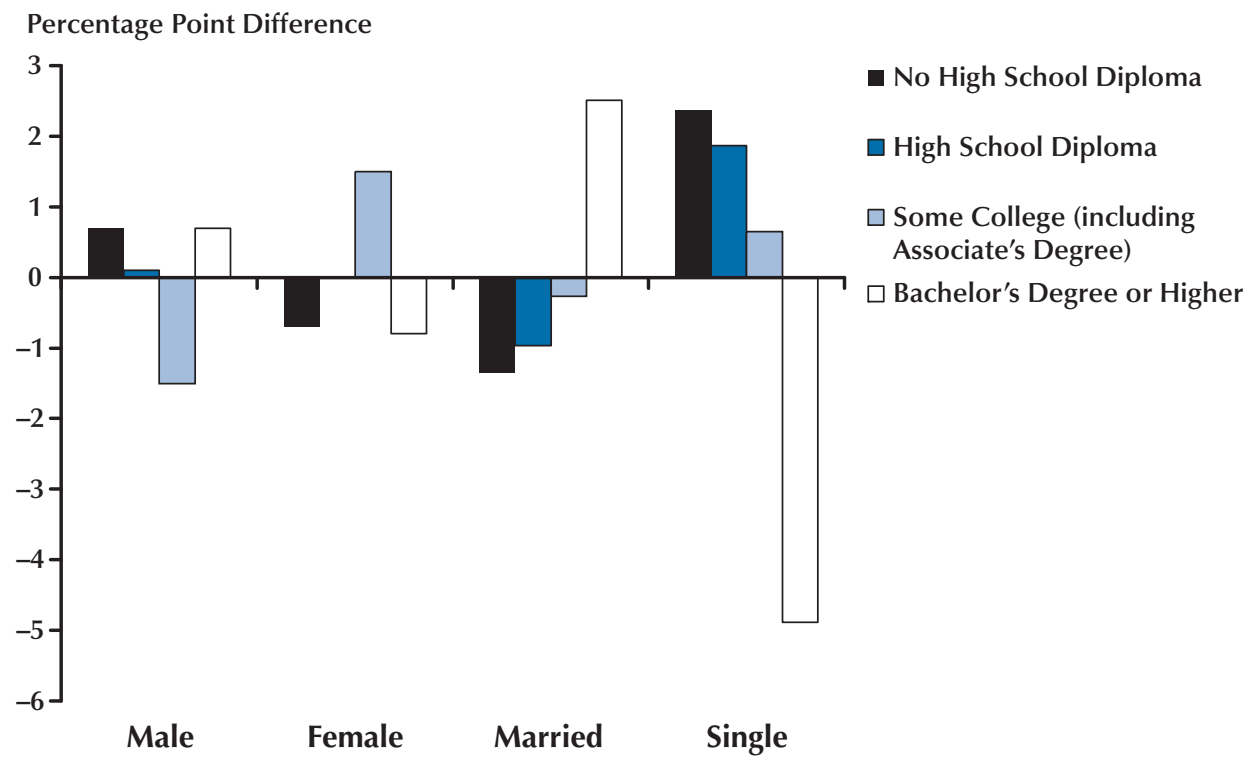

\section{Figure 21}

Educational Attainment, 25 Years and Older: 2007 (Difference from the Total: Race)

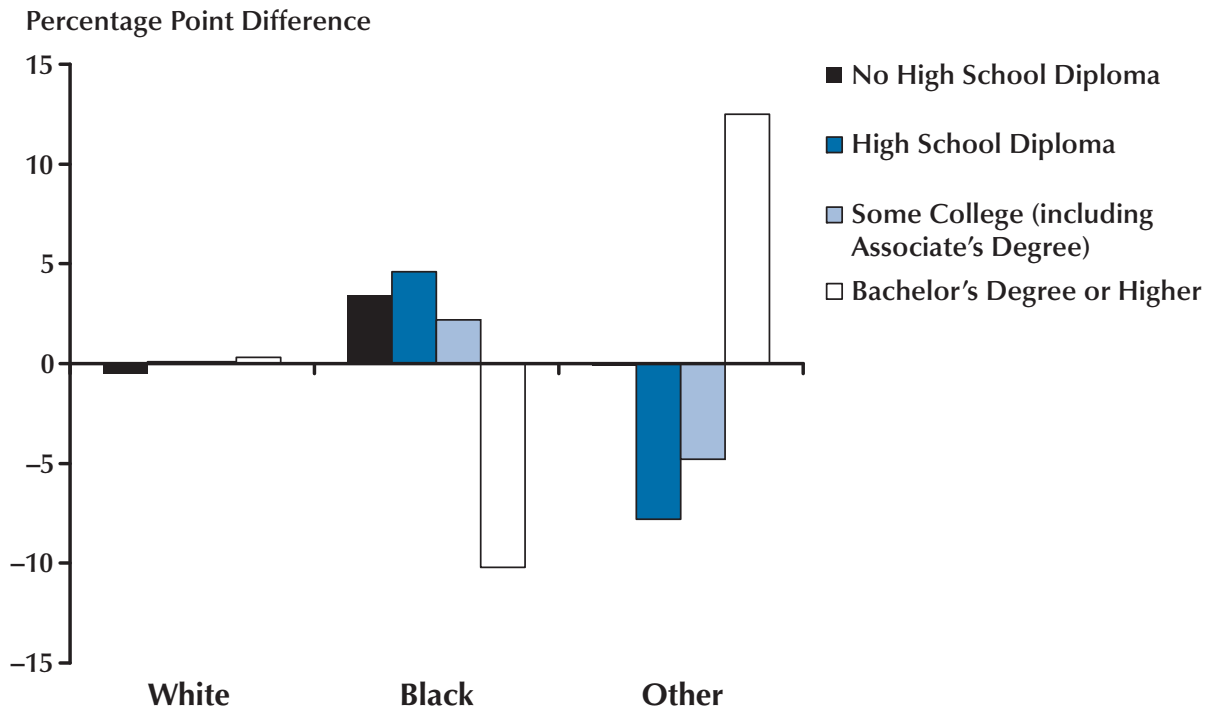




\section{Engemann and Wall}

\section{REFERENCES}

DeRiviere, Linda. "Have We Come a Long Way? Using the Survey of Labour and Income Dynamics to Revisit the 'Pin Money' Theory.” Journal of Socio-Economics, December 2008, 37(6), pp. 2340-67.

DiCecio, Riccardo; Engemann, Kristie M.; Owyang, Michael T. and Wheeler, Christopher H. "Changing Trends in the Labor Force: A Survey.” Federal Reserve Bank of St. Louis Review, January/February 2008, 90(1), pp. 47-62; http://research.stlouisfed.org/publications/review/08/01/DiCecio.pdf.

Goodman, William; Antczak, Stephen and Freeman, Laura. "Women and Jobs in Recessions: 1969-92." Monthly Labor Review, July 1993, 116(7), pp. 26-35.

Hoff Sommers, Christina. "No Country for Burly Men.” The Weekly Standard, June 29, 2009, 14(39); www.weeklystandard.com/Content/Public/Articles/000/000/016/659dkrod.asp.

Mankiw, Greg. “This Recession’s Gender Gap.” June 7, 2009; http://gregmankiw.blogspot.com.

Owyang, Michael T.; Piger, Jeremy and Wall, Howard J. "A State-Level Analysis of the Great Moderation." Regional Science and Urban Economics, November 2008, 38(6), pp. 578-89.

Stephens, Melvin Jr. "Worker Displacement and the Added Worker Effect.” Journal of Labor Economics, July 2002, 20(3), pp. 504-37.

Wall, Howard J. “The 'Man-Cession' of 2008-09: It's Big, but It's Not Great.” Federal Reserve Bank of St. Louis The Regional Economist, October 2009, pp. 4-9;

http://research.stlouisfed.org/publications/regional/09/10/mancession.pdf. 


\section{APPENDIX A}

\section{Table A1}

The Timing of Official Recessions and Employment Recessions

\begin{tabular}{lcc} 
Recession & NBER Dates & Household Employment Dates \\
\hline $1974-75$ & $1974: Q 1-1975: Q 1$ & $1974: Q 4-1975: Q 2$ \\
1980 & $1980: Q 2-1980: Q 3$ & $1980: Q 2-1980: Q 3$ \\
$1981-82$ & $1981: Q 4-1982: Q 4$ & $1981: Q 3-1983: Q 1$ \\
$1990-91$ & $1990: Q 4-1991: Q 1$ & $1990: Q 2-1991: Q 4$ \\
2001 & $2001: Q 2-2001: Q 4$ & $2001: Q 2-2002: Q 1$ \\
$2007-09$ & $2008: Q 1-?$ & $2007: Q 2-?$
\end{tabular}

NOTE: The official recession dates are determined by the NBER. The dates for household employment recessions are estimated with a Markov-switching model.

\section{Figure A1}

\section{Household Employment Growth Rate (1972-2009) Quarterly, Seasonally Adjusted}

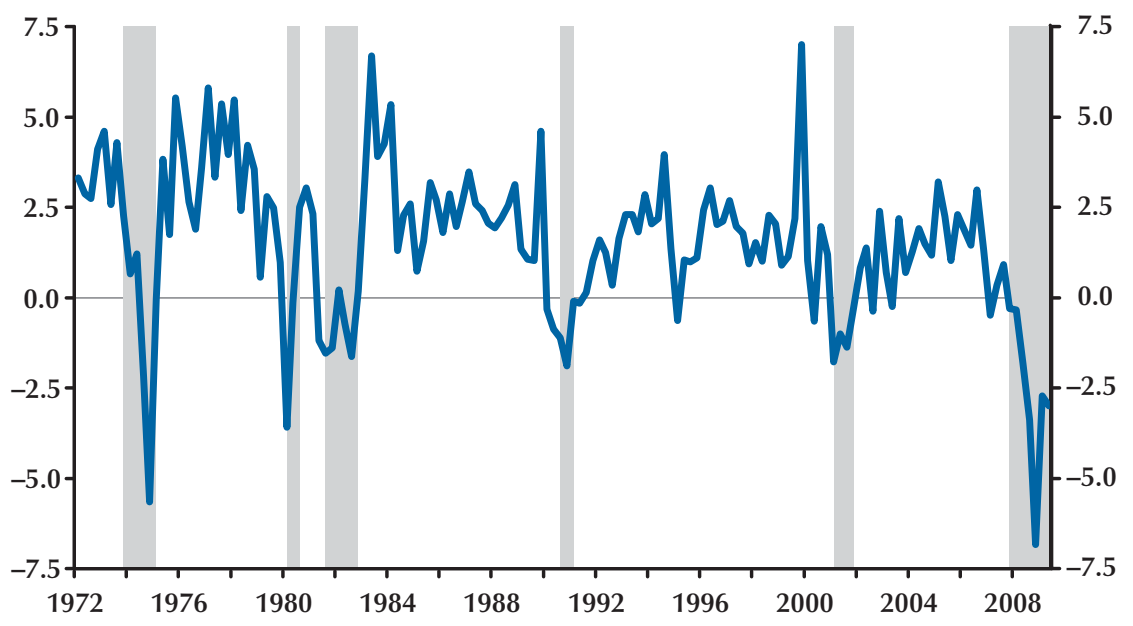

NOTE: Gray bars indicate official NBER recessions.

SOURCE: BLS/Haver Analytics. 


\section{APPENDIX B}

\section{Figure B1}

Employment-to-Population Ratio for the Sexes (1972-2009) Overall, by Marital Status, Race, and Age
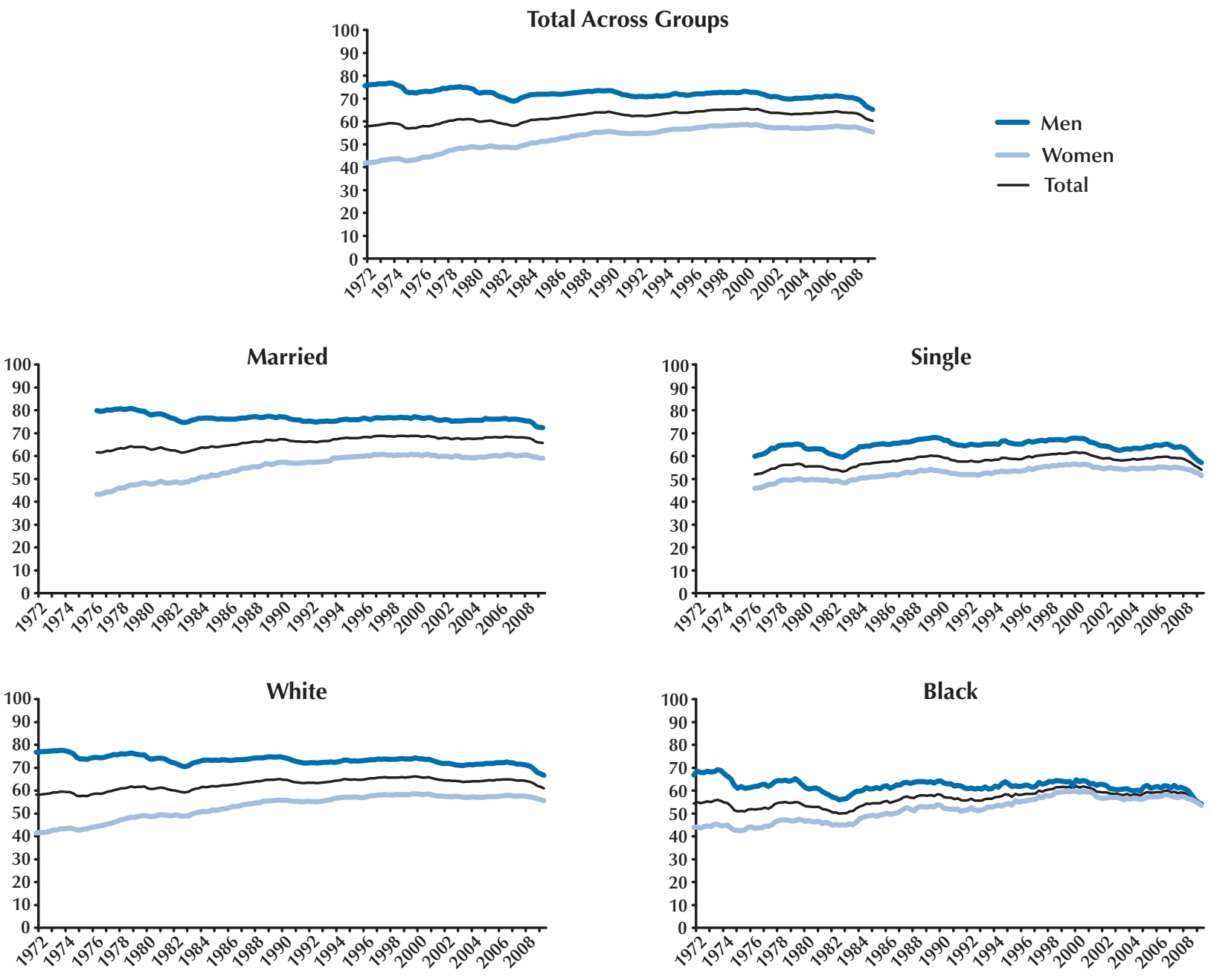
Engemann and Wall

APPENDIX B

Figure B1, cont'd

Employment-to-Population Ratio for the Sexes (1972-2009) Overall, by Marital Status, Race, and Age
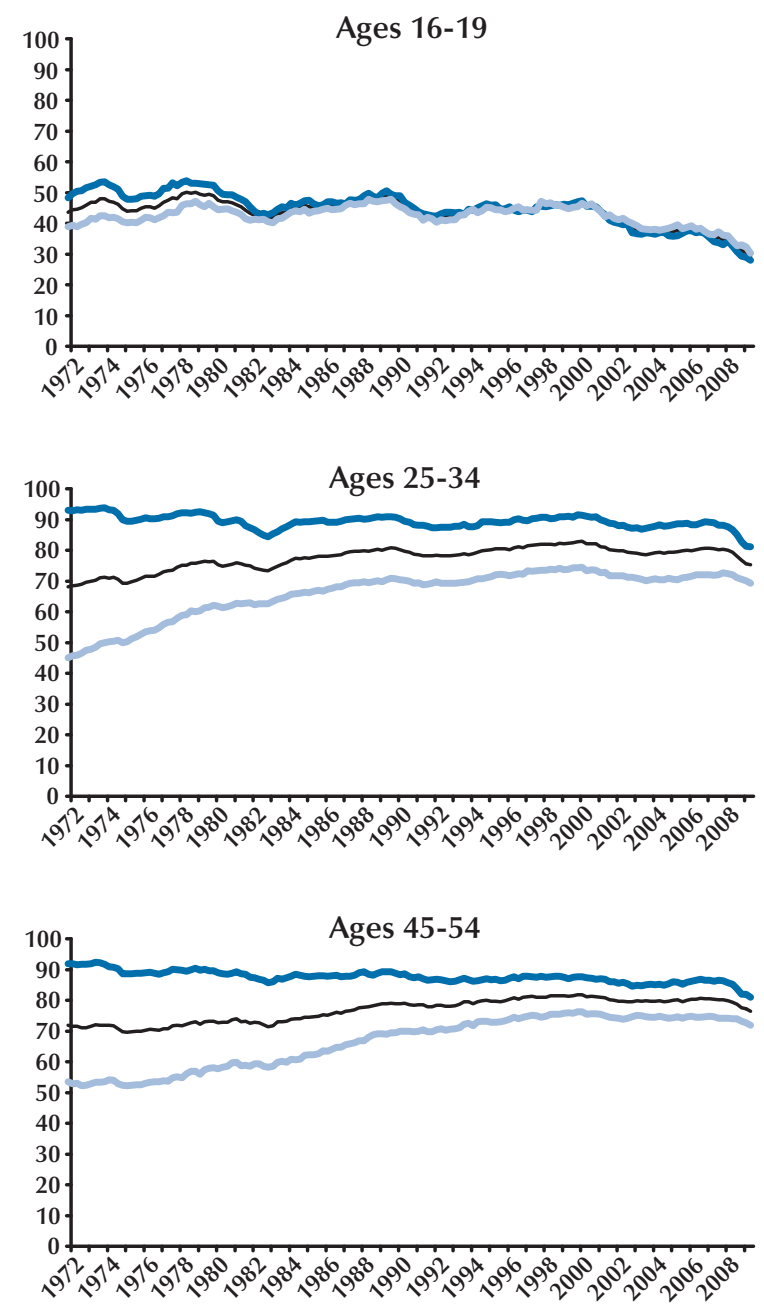
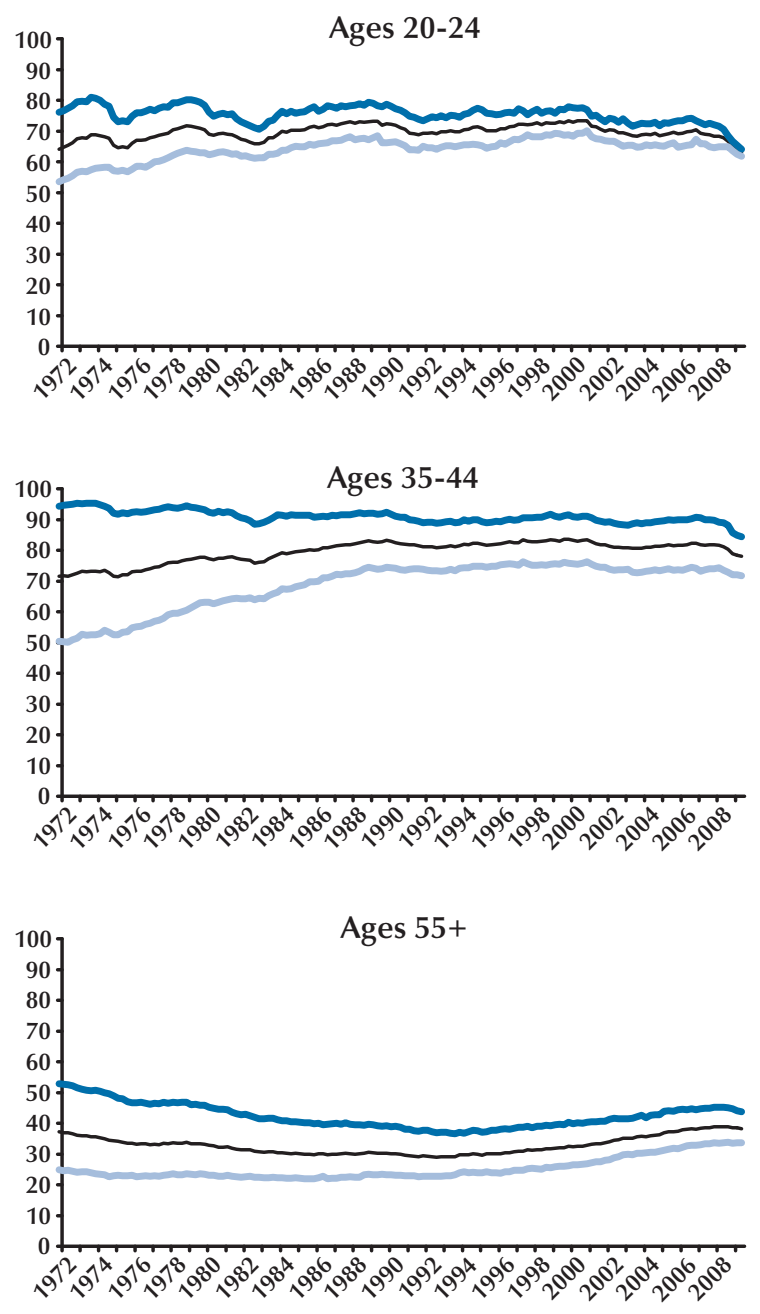

FEDERAL RESERVE BANK OF ST. LOUIS REVIEW

JANUARY/FEBRUARY 2010

25 


\section{APPENDIX C}

\section{Table C1}

\section{Median Employment Growth Rates (Annual)}

A. Aggregate and by marital status

\begin{tabular}{|c|c|c|c|c|c|c|}
\hline & & gate & & & & \\
\hline & $1972-84$ & 1985-2009 & 1972-84 & $1985-2009$ & $1972-84$ & 1985-2009 \\
\hline Total & 2.5 & 1.3 & 1.6 & 1.0 & 3.7 & 1.7 \\
\hline Men & 1.9 & 1.0 & 0.7 & 0.7 & 4.7 & 1.6 \\
\hline Women & 3.4 & 1.7 & 3.4 & 0.9 & 3.7 & 1.4 \\
\hline
\end{tabular}

B. By race

\begin{tabular}{|c|c|c|c|c|c|c|}
\hline & & & & & & \\
\hline & $1972-84$ & 1985-2009 & 1972-84 & 1985-2009 & $1972-84$ & 1985-2009 \\
\hline Total & 2.5 & 1.2 & 2.1 & 1.5 & 8.0 & 3.3 \\
\hline Men & 1.7 & 1.0 & 2.0 & 1.0 & 9.0 & 3.3 \\
\hline Women & 3.1 & 1.2 & 3.0 & 2.2 & 4.6 & 4.4 \\
\hline
\end{tabular}

C. By age group

\begin{tabular}{|c|c|c|c|c|c|}
\hline 16-19 Years & 20-24 Years & 25-34 Years & 35-44 Years & 45-54 Years & $55+$ Years \\
\hline $1972-84 \quad 1985-2009$ & 1972-84 1985-2009 & $1972-84 \quad 1985-2009$ & $1972-84 \quad 1985-2009$ & $1972-84 \quad 1985-2009$ & $1972-84198$ \\
\hline
\end{tabular}

\begin{tabular}{lrrrrrrrrrrrr}
\hline Total & -0.4 & 0.0 & 2.4 & -0.6 & 5.3 & -0.2 & 3.6 & 1.2 & 0.1 & 3.1 & -0.1 & 2.4 \\
Men & -0.4 & -0.5 & 2.2 & -0.8 & 4.1 & -0.4 & 2.5 & 1.1 & -0.4 & 2.5 & -0.6 & 2.0 \\
Women & -0.2 & -0.8 & 2.6 & -0.3 & 5.9 & 0.1 & 5.0 & 1.7 & 0.7 & 3.2 & 0.4 & 2.8 \\
\hline
\end{tabular}

